\title{
Chemosensory response of the Phaseolus vulgaris L. (Fabaceae) weevil (Bruchus chinensis LINNAEuS, 1758 (Coleoptera: Bruchidae)) to Dioscorea sansibarensis PAX. (Dioscoreaceae) bulbil essential oil
}

\author{
Godfrey Omare Mauti ${ }^{1 *}$, Peter F. Kasigwa ${ }^{1}$, JoAn J.E. Munissi ${ }^{2}$, \\ JuSTUS M. ONGUSO ${ }^{3}$
}

${ }^{1}$ Department of Zoology and Wildlife Conservation, College of Natural and Applied Sciences University of Dar es Salaam, Dar es Salaam, Tanzania

${ }^{2}$ Chemistry Department, College of Natural and Applied Sciences, University of Dar es Salaam, Dar es Salaam, Tanzania

${ }^{3}$ Institute of Biotechnology Research, Jomo Kenyatta University of Agriculture and

Technology, Nairobi, Kenya

\begin{abstract}
Dioscorea sansibarensis bulbils are well known for their toxicity and medicinal applications. In this study, the attraction and mortality of the Phaseolus vulgaris weevil (Bruchus chinensis) caused by Dioscorea sansibarensis bulbil oil was examined in a Completely Randomized Design experiment using a Y-tube olfactometer on a laboratory bench. Statistical analysis at $P<0.05$ showed $10 \mu \mathrm{L}$ had an attraction of $42.67 \%$. In the case of mortality, the results showed that Phaseolus vulgaris seeds treated with $40 \mu \mathrm{L}$ of the bulbil oil had a harmonic mean of $55.8 \%$ mortality of the weevil population, which was higher than with $10 \mu \mathrm{L}$ of Actellic $50 \mathrm{EC}$. GC-MS analysis identified 17 compounds in the bulbil oil, the main constituents of which were 2pentanone, 4-hydroxy-4-methyl- (17.8\%), phenol, 4-ethyl- (11.41\%), hexadecanoic acid, methyl ester (11.05\%), phenol (7.35\%), 9-octadecenoic acid, (E)- (7.2\%) and phenol, 4-ethyl-2-methoxy(7.14\%). Attraction by bulbil oil may have been due to the presence of phenolic compounds, and mortality may have been due to hexadecanoic acid, methyl ester and 9-octadecenoic acid, (E)-. Attractants are used for the surveillance and detection of an infestation in stored products. The added advantage of the bulbil oil to cause mortality makes Dioscorea sansibarensis bulbil oil useful in the formulation of a botanical pesticide in stored pest management.
\end{abstract}

KEY WORDS: Attraction, Bruchus chinensis, Dioscorea sansibarensis bulbil oil, Mortality, GCMS, Y- tube olfactometer.

* Corresponding author: godiomari@yahoo.com 


\section{INTRODUCTION}

Bruchus chinensis (LINNAEUS, 1758), also known as Callosobruchus chinensis (LINNAEUS, 1758), is a pest species belonging to the Bruchidae family. It causes serious damage to the common bean (Phaseolus vulgaris L.) and has a remarkably high rate of reproduction over a short period of time. The female migrates by flying to find better egg laying surfaces (GBAYE et al. 2012). Damage by the Bruchus chinensis beetle occurs after the larva hatches from the egg and develops within the seed, where it eats the seed's internal tissue before emerging as an adult and leaving the seed as an empty husk (CHAUBEY 2014).

Plants contain secondary metabolites that, once eaten by some animals, insects and microbial pathogens, lead to their death. These plants produce a scent that acts as an attractant to pollinators and seed-dispersing animals. Such characteristics have given plants different medicinal, antimicrobial and insectivorous properties, and hence, uses (STEVENSON et al. 2017, WINK 2018). Natural products of plant origin in the form of powders, slurries, aqueous/solvent extracts or oils have been tried as insecticides. These plant extracts have secondary metabolites that influence the physiology and behaviour of insect pests involving toxicity, repellency/attraction and anti-feeding effects (UPADHYAY \& AHMAD 2011, SALEHI et al. 2014).

Although numerous reports exist on the repellent activities of plant essential oils, fewer data have been published regarding their properties as attractants to Bruchus chinensis weevils. Chemical attraction is used in the behavioural control of insects; for instance, the aroma of baker's yeast produced by Saccharomyces cerevisiae MEYEN ex E.C. HANSEN and Kluyveromyces lactis (DOMBROWSKI) attracts Bruchus chinensis and the coffee bean weevil (Araecerus fasciculatus (DE GEER, 1775)) (GRAMATICA et al. 1985, YANG et al. 2017).

With the use of Y-tube olfactometry, odours from essential oils retrieved from blueberry (Vaccinium corybosum L.), cucumber (Cucumis sativus L.), capsicum (Capsicum annum L.), chrysanthemum (Chrysanthemum morifolium RAMAT.), clove basil (Ocimum gratissimum L.) and lavender (Lavandula angustifolia L.) were found to attract cranberry weevils (Anthonomus musculus SAY, 1831) and raspberry weevils (Aegorhinus superciliosus (GUÉRIN-MÉNEVILLE, 1830)) (KOSCHIER et al. 2017, CURKOVIC et al. 2018). HADDI et al. (2018) reported that essential oils recovered from clove (Syzygium aromaticum (L.) MERR. \& PERRY) and cinnamon (Cinnamomum verum J. PRESL) caused both the attraction and death of the bean weevil (Acanthoscelides obtectus (SAY, 1831)). A combination of plant oils was found to possess anti-weevil activities, for example, when a mixture of sesame and neem oils applied to mung beans attracted and then killed Bruchus chinensis and Callosobruchus maculatus (FABRICIUS, 1775) (TALEKAR 1988). 
Dioscorea sansibarensis PAX. (Zanzibar yam) is a sun-loving, ornamental climber found along the edges of riparian forests in the coastal regions of Tanzania and Madagascar (BURKILL 1985). The plant produces smooth-surfaced, dark purplish to brown bulbils in the leaf axils, which can reach $6 \mathrm{~cm}$ or more in diameter. Toxic and inedible, these bulbils are frequently produced to facilitate the plant's dispersal (WALSH 2009). D. sansibarensis is grown by farmers around yam farms in order to persuade potential thieves and monkeys to steal it rather than the main crop of more valuable yams (MAURIN et al. 2016).

When mashed into a paste, the $D$. sansibarensis bulbil has a pleasant and intense aroma. Traditionally, this bulbil has been used for medicinal purposes; of late it has attracted pharmaceutical interest (BURKILL 1985, MAURIN et al. 2016). The bulbil's curative properties are due to the presence of certain bioactive compounds, although there is no scientific rationale to back this up (KUMAR et al. 2017). A literature survey shows that the D. sansibarensis plant contains chemical compounds which protect it against bacterial attack and fungi (KUMAR et al. 2017). A study by MAUTI et al. (2019) showed that the leaf oil derived from D. sansibarensis repels Bruchus chinensis weevils, but no research has yet been conducted on the attractive and insecticidal properties of Dioscorea sansibarensis against Bruchus chinensis. The present study focused on determining the attractive potency and lethal activity of the essential oil derived from the bulbil of Dioscorea sansibarensis against the stored-legume pest Bruchus chinensis and on analysing its chemical composition using gas chromatography-mass spectrometry (GC-MS).

\section{MATERIALS AND METHODS}

\section{Materials}

Healthy dry common bean seeds Phaseolus vulgaris were purchased directly from a farm after harvest and stored with $10 \pm 2 \%$ moisture content. The Y-tube olfactometers for this work were constructed in the glass-blowing section of the Chemistry Department of the University of Dar es Salaam (UDSM), Tanzania. Acetone (analytical grade) was purchased from Chemical and Equipment Laboratory Suppliers in Tanzania. The commercial synthetic pesticide, Actellic 50 EC (500g/L AI, Syngenta, Switzerland), was purchased from Ubungo Agricultural Input Suppliers in Dar es Salaam for use as the positive control in the mortality test of Bruchus chinensis.

\section{Collection and preparation of plant materials}

Fresh bulbils of Dioscorea sansibarensis were identified and harvested from the Zoology-Botany forest of UDSM ( $6^{\circ} 45^{\prime} 0^{\prime \prime}$ S, $39^{\circ} 15^{\prime} 0^{\prime \prime}$ E, altitude $80 \mathrm{~m}$ a.s.l.). Further 
morphological identification was carried out in the herbarium of the Botany Department of UDSM and allocated the voucher reference number FMM $3910 \mathrm{~b}$.

\section{Extraction of essential oil}

Fresh aerial bulbils of $D$. sansibarensis were collected, washed, rinsed with distilled water and then macerated into small pieces. The pieces were air dried for 5 days at the entomology laboratory of UDSM. After drying, $250 \mathrm{~g}$ of bulbils were ground and homogenized to a powder using an electric grinder. The essential oil was extracted from the powdered bulbil for 4 hours by hydro-distillation in a Clevenger apparatus. The oil was concentrated under vacuum at $40{ }^{\circ} \mathrm{C}$ and stored in a refrigerator at $4{ }^{\circ} \mathrm{C}$ for the bioassays.

\section{Determination of the essential oil components}

The identity of the essential oil constituents was established by GC-MS (a HewlettPackard HP 5973 mass spectrometer interfaced with an HP 6890 gas chromatograph). The mass selective detector was operated in electron impact mode with an ionization energy of $70 \mathrm{eV}$ and a mass range from $\mathrm{m} / \mathrm{z} 40$ - 380. The temperature of the HP-5 column ( $30 \mathrm{~m}$ long and $0.25 \mathrm{~mm}$ internal diameter with a film thickness of $0.25 \mu \mathrm{m}$ ) was initially maintained at $60{ }^{\circ} \mathrm{C}$, then gradually increased to $250{ }^{\circ} \mathrm{C}$ at a rate of $5{ }^{\circ} \mathrm{C} / \mathrm{min}$. Helium (99.9\%) was used as the carrier gas. The temperature and its rate of increase were adjusted if peak separation was inadequate. Each sample was dissolved in hexane to give a $1 \% \mathrm{w} / \mathrm{v}$ solution; $0.2 \mu \mathrm{L}$ of the oil sample was injected at $250{ }^{\circ} \mathrm{C}$ into the GC-MS equipment from which the gas chromatograms and mass spectra were obtained. The gas chromatograms were used for the quantitative analysis of the individual constituents. The mass spectra were used for identifying the constituents by matching their spectra to those recorded in the Wiley 275 and NIST Mass Spectral Library with reference to the associated database and literature.

\section{Rearing of test weevils}

One kg of dry, undamaged and healthy Phaseolus vulgaris beans were dried in an oven at $60{ }^{\circ} \mathrm{C}$ for 1 hour. They were placed in glass jars $(27 \mathrm{~cm}$ height $\times 16 \mathrm{~cm}$ diameter). Approximately 350 adults of the collected Bruchus chinensis weevils were released into the jar and the mouth subsequently covered with muslin cloth and secured with a rubber band. The bottles were then incubated in darkness at $28 \pm 2{ }^{\circ} \mathrm{C}$ and $65 \pm 5 \%$ relative humidity for mating and oviposition for 2 weeks. The weevils were then separated from the seeds by sieving and the seeds returned to their container for continued incubation. The F1 progeny aged two weeks were selected for the bioassay. 


\section{Chemosensory bioassay}

The attractive activity of the bulbil oil on B. chinensis was assessed using a Y-shaped olfactometer. The Y-tube was placed in the centre of a black box of dimensions $23 \mathrm{x} 16 \mathrm{x}$ $11 \mathrm{~cm}$, lined with black paper in order to avoid visual stimuli produced by the halogen lamp when switched on. The Y-tube olfactometer consisted of a Y-shaped glass tube with three compartments (arms), each $1 \mathrm{~cm}$ in diameter and $10 \mathrm{~cm}$ long. These compartments were the treatment arm, the control arm and the arm for introducing weevils. The end of each arm was closed with a $3 \mathrm{~cm}$ diameter glass stopper. The stoppers had two narrow grooves allowing air to flow into the olfactometer during the bioassays.

Filter paper discs (Whatman No.1, diameter $1 \mathrm{~cm}$ and weight $140 \mathrm{mg}$ ) were dipped into dilutions of bulbil oil 10, 20, 30 and $40 \mu \mathrm{L}$ per $1 \mathrm{~mL}$ of acetone and allowed to air-dry. Acetone was used to sterilize the filter paper disc that was used as the negative control disc. The discs were inserted into the treatment compartments, after which air-suction through a Tygon tube was applied at the Y-junction by means of an aspirator pump before the introduction of the weevils. This ensured that the olfactometer did not become saturated with the vapour from the oil, which was confined to the treatment arm of the olfactometer. The insects were induced by light and allowed to walk and decide which arm to enter at the bifurcation.

Ten pairs of weevils were selected for each assay and introduced at once into the olfactometer. Advantage was taken of the fact that weevils are negatively phototactic by illuminating the introduction compartment of the weevils into the olfactometer with light from a 60-watt bulb placed $15 \mathrm{~cm}$ away and screening the rest of the olfactometer in a cardboard box. An average of $80-85 \%$ of the weevils was thus induced to migrate from the introduction arm to either the control or treatment arm during the bioassay. This was run for one hour, after which the numbers of weevils in the control arm (NC) and treatment arm (NT) were counted. The percentage attraction (\% PA) was calculated using the formula (source):

$$
\% \mathrm{PA}=\{(\mathrm{NT}-\mathrm{NC}) /(\mathrm{NT}+\mathrm{NC})\} \times 100,
$$

where $\% \mathrm{PA}$ is the percentage attraction, $\mathrm{NC}$ is the number of weevils in the control arm and NT is the number of weevils in the treatment arm.

\section{Bruchus chinensis mortality test}

About $50 \mathrm{~g}$ of clean, disinfected, common bean seeds were weighed into sterilized glass bottles. Concentrations of bulbil oil $(0.036,0.072,0.108$ and $0.144 \mathrm{mg} / \mathrm{mL})$ and Actellic 50 EC $(0.01,0.02,0.03$ and $0.04 \mathrm{mg} / \mathrm{mL})$ were made by respectively diluting $10,20,30$ and 40 $\mu \mathrm{L}$ of oil or Actellic $50 \mathrm{EC}$ in $5 \mathrm{~mL}$ of acetone. Each dilution was then mixed with the bean 
seeds. Beans sterilized by acetone were used as the negative control. Ten pairs of newly emerged adult weevils were introduced to the treated and untreated bean seeds in the glass bottles and covered with a muslin cloth. Each experiment was replicated four times. The experiment was arranged in a Completely Randomized Design on a laboratory bench. The number of dead insects were recorded every 24 hours for 5 days. Percentage mortality was computed using the method adopted by Аввотт (1925).

\section{Statistical analyses}

All recorded data on weevil attraction and mortality were converted to percentages and the means compared by Duncan's New Multiple Range Test (DMRT) using the statistical programme Minitab 2017 version 18. ANOVA was used to determine the differences in the effectiveness of bulbil oil at different concentrations using SPSS software Version 20, including a normality test, homogeneity distribution and post-hoc analysis utilizing the Tukey HSD test at $\mathrm{P} \leq 0.05$. The independent variables in this model were the treatment doses and the duration of exposure, while the dependent variables were the percentage attraction and mortality.

Table 1. Chemical composition of the essential oil extracted from the bulbil of Dioscorea sansibarensis.

\begin{tabular}{rlrrr}
\hline No. & \multicolumn{1}{c}{ Constituents } & $\mathbf{M M}^{\mathbf{a}}$ & $\mathbf{R T}^{\mathbf{b}}$ & $\mathbf{\%}^{\mathbf{c}}$ \\
\hline 1. & 2-Pentanone, 4-hydroxy-4-methyl- & 116 & 5.05 & 17.8 \\
2. & Phenol & 94 & 10.08 & 7.35 \\
3. & 2-Octanol, (S)- & 130 & 10.47 & 1.51 \\
4. & Phenol, 2-methyl- & 108 & 12.40 & 1.60 \\
5. & p-Cresol & 108 & 13.07 & 4.67 \\
6. & Phenol, 2-methoxy- & 124 & 13.28 & 5.39 \\
7. & Phenol, 2-ethyl- & 122 & 15.00 & 2.80 \\
8. & Phenol, 2,4-dimethyl- & 122 & 15.27 & 1.25 \\
9. & Phenol, 4-ethyl- & 122 & 15.86 & 11.41 \\
10. & Benzenepropanenitrile & 131 & 17.82 & 3.80 \\
11. & Phenol, 4-ethyl-2-methoxy- & 152 & 18.93 & 7.14 \\
12. & Indole & 117 & 19.38 & 6.21 \\
13. & Hexadecanoic acid, methyl ester & 270 & 33.87 & 11.05 \\
14. & 9,12-Octadecadienoic acid $(Z, Z)-$, methyl ester & 294 & 37.03 & 4.35 \\
15. & 6-Octadecenoic acid, methyl ester, $(Z)-$ & 296 & 37.15 & 3.95 \\
16. & 9-Octadecenoic acid, $(E)-$ & 282 & 37.96 & 7.20 \\
17. & 1-Heptacosanol & 396 & 43.64 & 2.53 \\
\hline
\end{tabular}

\footnotetext{
${ }^{\mathrm{a}}$ Molar mass (g/mol) ${ }^{\mathrm{b}}$ Retention time (minute); ${ }^{\mathrm{c}}$ Percentage composition of a compound.
} 


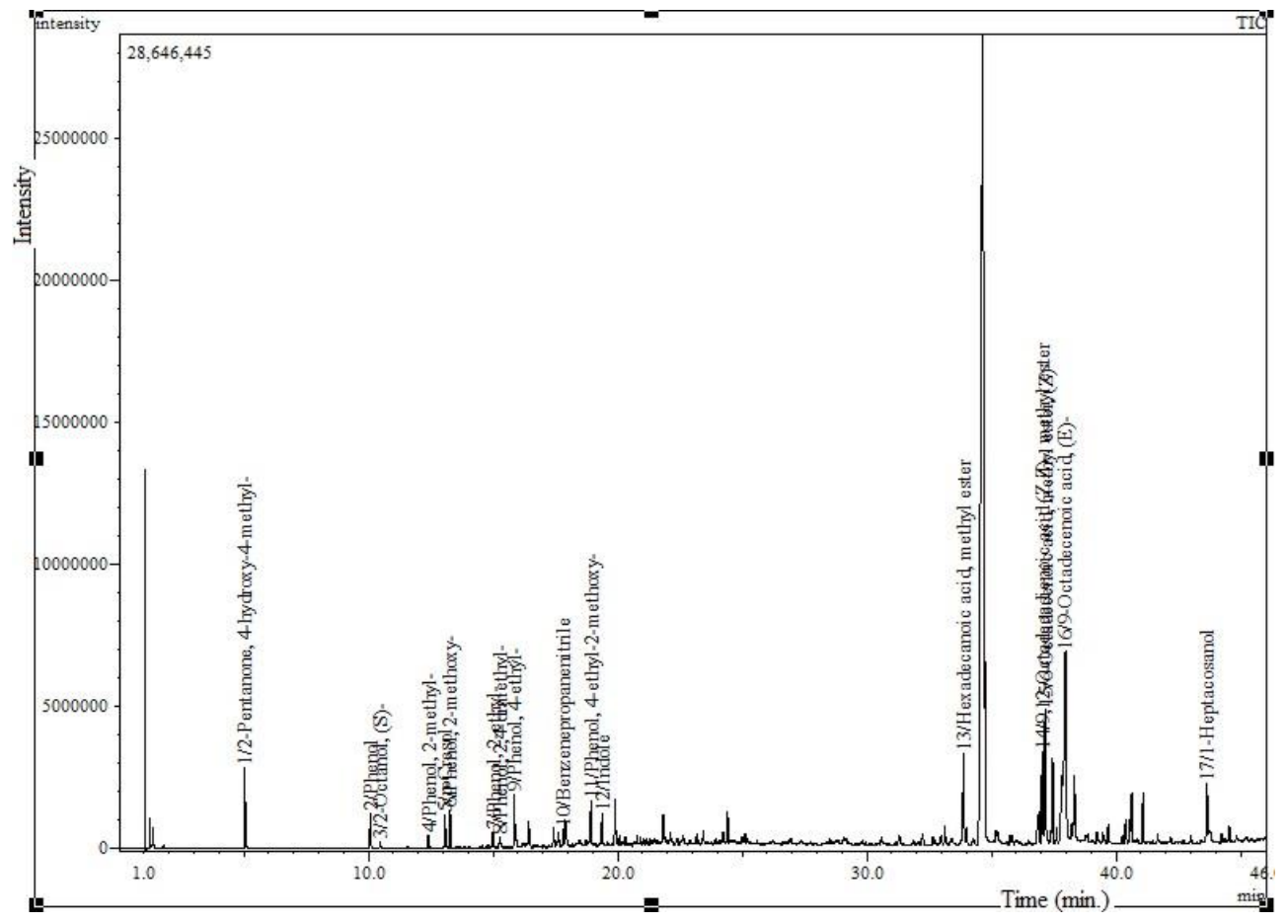

Fig. 1. GC-MS chromatogram of the essential oil of the bulbil of Dioscorea sanisbarensis.

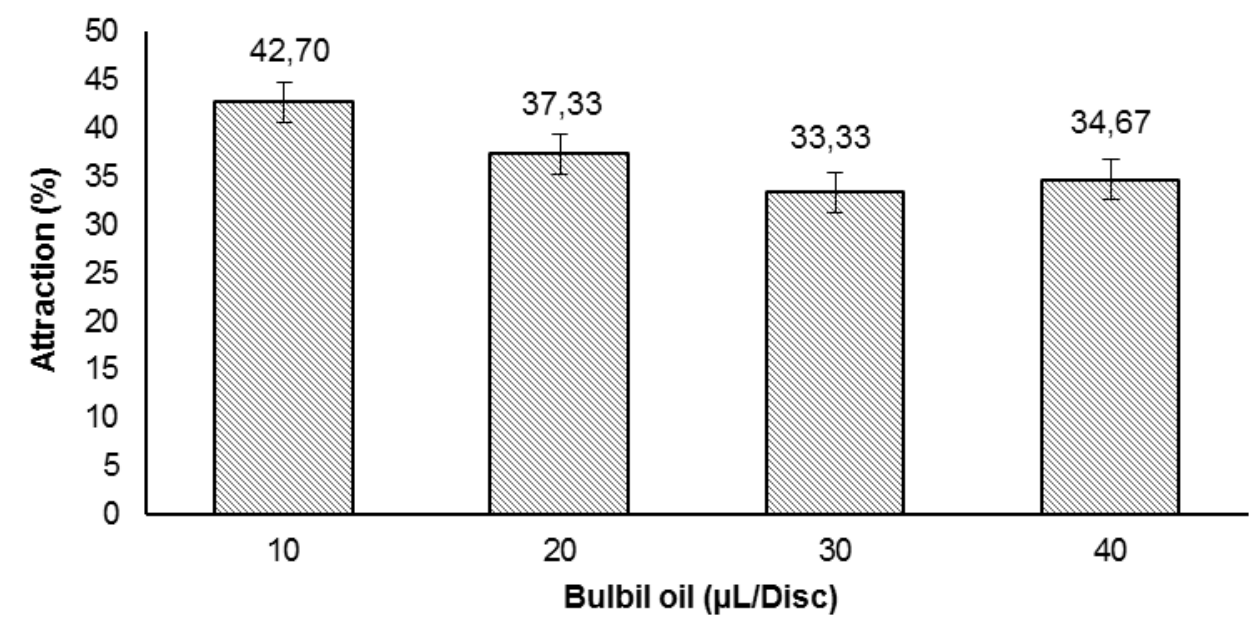

Fig. 2. Attraction of Bruchus chinensis to Dioscorea sansibarensis bulbil essential oil measured using a Y-tube olfactometer ( $\mathrm{N}=200 ; P<0.05$ using Tukey’s HSD test). 


\section{RESULTS}

\section{Constituents of essential oils}

Dioscorea sansibarensis bulbils yielded $0.43 \pm 0.03 \%$ (w/w) of oil with a density of $0.36 \pm 0.05 \mathrm{~g} / \mathrm{mL}$. GC-MS analysis revealed a total of 17 compounds eluted in the GC-MS analyser during 45 minutes. The main components and their percentage compositions were 2-pentanone, 4-hydroxy-4-methyl- (17.8\%); phenol, 4-ethyl- (11.41\%); hexadecanoic acid, methyl ester (11.05\%); phenol (7.35\%); 9-octadecenoic acid, $(E)$ - $(7.2 \%)$ and phenol, 4ethyl-2-methoxy- (7.14\%) (Table 1 and Fig. 1). The bioassay results showed that the bulbil oil acted as an attractant to Bruchus chinensis.

\section{Chemosensory bioassay using the $\mathbf{Y}$-tube olfactometer}

In this study, Dioscorea sansibarensis bulbil oil attracted Bruchus chinensis weevils. The $30 \mu \mathrm{L}$ dilution of bulbil oil exhibited an attraction of $33.33 \%$ as compared to the $10 \mu \mathrm{L}$ dilution (42.70\%) (Fig. 2). The sample size $(\mathrm{N}=200)$ had a normal distribution: Levene's test revealed that the data were heterogeneously distributed at $\mathrm{L}(7,192)=9.143 ; P<0.05$. Tests of within-subject effects showed that the oil treatments influenced $91.2 \%\left(\mathrm{R}^{2}=0.912\right)$ of the total weevil attraction at $\mathrm{F}=283.283 ; P<0.05$. Statistically, the $10 \mu \mathrm{L}$ dilution of bulbil oil had a higher attraction activity than the $20 \mu \mathrm{L}$ or $30 \mu \mathrm{L}$ dilutions.

\section{Mortality test}

The tabulated results show that on the first day of weevil exposure to the common beans treated with different concentrations of bulbil oil and Actellic $50 \mathrm{EC}, 20 \mu \mathrm{L}$ of bulbil oil elicited a higher mortality rate than $10 \mu \mathrm{L}$ of Actellic $50 \mathrm{EC}$ (Table 2). The data $(\mathrm{N}=640)$ were subjected to statistical analysis. The Shapiro-Wilk test showed a normal distribution of the data as Levene's test recorded a heterogeneous distribution at $(F(39,600)=24.256$; $P<0.05)$. Testing the between-subject effect showed that bulbil oil influenced $88.6 \%\left(\mathrm{R}^{2}=\right.$ 0.886 ) of the results on mortality. Statistically, $30 \mu \mathrm{L}$ of bulbil oil with a harmonic mean of $38.72 \%$ had a homogeneous mortality activity equivalent to $10 \mu \mathrm{L}$ of Actellic $50 \mathrm{EC}$, which had a harmonic mean of $42.13 \%$. The results showed that $40 \mu \mathrm{L}$ of bulbil oil with a harmonic mean of $55.8 \%$ elicited a higher mortality than $10 \mu \mathrm{L}$ of Actellic $50 \mathrm{EC}$. 
Table 2. Mortality of Bruchus chinensis weevils reared for 5 days on Phaseolus vulgaris seeds treated with different concentrations of Dioscorea sansibarensis bulbil oil and Actellic 50 EC. Conc. - contentration $[\mu \mathrm{l} / 50 \mathrm{~g}]$.

\begin{tabular}{lcrrrrr}
\hline Treatment & Conc. & \multicolumn{5}{c}{ Mean \% mortality at days after post-treatment \pm S.E } \\
\cline { 2 - 7 } & & \multicolumn{1}{c}{ Day 1 } & \multicolumn{1}{c}{ Day 2 } & \multicolumn{1}{c}{ Day 3 } & \multicolumn{1}{c}{ Day 4 } & \multicolumn{1}{c}{ Day 5 } \\
\hline \multirow{3}{*}{ Bulbil oil } & 10 & $0.00 \pm 0.00$ & $2.92 \pm 1.72$ & $5.81 \pm 2.27$ & $16.04 \pm 4.73$ & $25.10 \pm 8.86$ \\
& 20 & $9.02 \pm 1.16$ & $13.56 \pm 1.59$ & $28.57 \pm 4.34$ & $33.33 \pm 4.36$ & $45.05 \pm 7.35$ \\
& $30^{\mathrm{a}}$ & $11.45 \pm 3.64$ & $21.19 \pm 4.21$ & $29.77 \pm 4.45$ & $56.22 \pm 6.91$ & $74.97 \pm 6.79$ \\
& 40 & $26.86 \pm 6.14$ & $43.89 \pm 6.14$ & $48.73 \pm 5.24$ & $70.22 \pm 3.48$ & $89.33 \pm 5.23$ \\
& $10^{\mathrm{a}}$ & $5.14 \pm 2.05$ & $15.75 \pm 3.62$ & $39.66 \pm 5.35$ & $60.38 \pm 3.96$ & $89.74 \pm 4.02$ \\
Actellic & 20 & $67.80 \pm 3.75$ & $90.46 \pm 3.75$ & $97.06 \pm 2.94$ & $100.00 \pm 0.00$ & $100.0 \pm 0.00$ \\
50 EC & 30 & $100.00 \pm 0.00$ & $100.00 \pm 0.00$ & $100.00 \pm 0.00$ & $100.00 \pm 0.00$ & $100.00 \pm 0.00$ \\
& 40 & $100.00 \pm 0.00$ & $100.00 \pm 0.00$ & $100.00 \pm 0.00$ & $100.00 \pm 0.00$ & $100.00 \pm 0.00$ \\
Untreated & 0 & $0.00 \pm 0.00$ & $0.00 \pm 0.00$ & $0.00 \pm 0.00$ & $0.00 \pm 0.00$ & $0.00 \pm 0.00$ \\
\hline
\end{tabular}

Treatments with the same letters in the table are not statistically significantly different from each other. $(\mathrm{N}=640),(P<0.05)$ using Tukey's HSD test.

\section{DISCUSSION}

Most research on fumigant insecticides focuses strongly on their repellent properties. Fewer studies have been carried out on the attraction potentiality of plant-based insecticides. The present one used Y-tube olfactometry to demonstrate that bulbil oil attracted Bruchus chinensis. Similarly, Bruchus chinensis weevils were attracted to oils of the water hyacinth (Eichhornia crassipes (MART.) SOLMS) (RANI \& JAMIL 1990). CHILUwal et al. (2017) likewise found attraction properties expressed by essential oils of Illicium verum HoOK.f., Bursera delpechiana PoISS. ex ENGL., Croton anisatum H.BN., Cinnamomum cassia (L.) J. PRESL and Aniba rosaeodora DUCKE to Bruchus chinensis using Y-tube olfactometry.

It was also found that high levels of both attraction and mortality of $B$. chinensis were obtained with the highest dose $(40 \mu \mathrm{L})$ of the bulbil oil. This was due to the high concentration of the active compounds from the zone of application. This upholds the findings on essential oils of different doses and various concentrations on the attraction of Coleopterans where a higher dosage increases attraction (NTONIFOR et al. 2010). Chiluwal et al. (2018) showed that the highest dose of essential oil from Gaultheria fragrantissima WALL. was found to attract many individuals of Bruchus chinensis.

In this study, attraction by bulbil oil could have been induced by the high content of phenolic compounds present in bulbil oil. This is supported by OWAGA et al. (1988), who 
reported that the presence of phenolic compounds was the major attractant of tsetse flies to buffalo urine. It was also reported that phenolic compounds applied to pumpkins elicited pheromone activity in the melon fruit fly (Bactrocera cucurbitae (COQUILLETT, 1849)) (Sharma \& SOHAL 2016). The phenolic compound p-cresol was found to attract Toxorhynchites THEOBALD, 1901 species (LINLEY 1989, NCHEKWUBE \& UZOH 2017). Furthermore, the phenolic compounds of coriander (Coriandrum sativum L.) and false fennel (Aneth graveolens L.) attracted and killed the wax moth (Galleria mellonella (LINNAEUS, 1758)) (OULEBSIR-MOHANDKACI et al. 2018). CHILUWAL et al. (2018) reported that the phenolic compounds in Gaultheria fragrantissima essential oil have been found to cause pheromones activity to Bruchus chinensis.

The B. chinensis weevils attracted to the treated Phaseolus vulgaris beans were killed. This was similar to the report by HADDI et al. (2018), where clove and cinnamon essential oil, applied to kidney beans and cranberries, attracted and killed the bean weevil Acanthoscelides obtectus. In this study, weevil mortality may have been enhanced by the presence in the bulbil oil of hexadecanoic methyl ester, 9-octadecenoic acid, (E)- and pcresol. The literature reports that hexadecanoic methyl ester and 9-octadecenoic acid, (E)possess pesticidal and insectifuge activity (TAYADE et al. 2013, ShibUla \& VelaVAN 2015). Essential oil of Ocimum basilicum L., with a high concentration of hexadecanoic methyl ester as one of its major components, exhibited insecticidal activity against Bruchus chinensis (RegnaUlt-Roger 1997). 9-octadecenoic acid, (E)- derived from Moringa oleifera LAM. and Cinnamomum aromaticum (L.) J. PRESL caused mortality in Bruchus maculatus and Callosobruchus chinensis (ISLAM et al. 2009, CuI et al. 2017, AJAY et al. 2018). The phenolic compound p-cresol may have increased weevil mortality owing to its pesticidal and antifeedant properties (MARCUS \& LICHTENSTEIN 1979, NCHEKWUBE 2017). Weevil mortality by bulbil oil may have been enhanced by the combination of lethal compounds that increased its toxicity to the target weevils.

\section{CONCLUSION}

Attractants are used for the surveillance and detection of infestations in stored products. Furthermore, the ability to kill the weevil is an added advantage in the control of storage pests. The findings of this study indicate the potential of Dioscorea sansibarensis bulbil oil for use in a formulation as an attractant in bean weevil management. Although this research has demonstrated the scientific uses of D. sansibarensis bulbil as a Bruchus chinensis attractant and as an antifeedant, further investigation of the mechanism of action of bioactive compounds extracted from the bulbil of Dioscorea sansibarensis is recommended. 


\section{ACKNOWLEDGEMENTS}

The authors would like to express their gratitude to DAAD-NAPRECA for the study scholarship [Reference number 91560175] for the research topic "Studies on the antifeedant properties of Dioscorea sansibarensis (PAX.) on Bruchus chinensis L. in the protection of stored Phaseolus vulgaris L. beans". We are grateful to Mr. Frank MBAGO of the Botany Departmental Herbarium for identifying the Dioscorea sansibarensis plant material, and to Dr. Fortunatus SunghwA of the Chemistry Department, University of Dar es Salaam, for facilitating the identification of Dioscorea leaf essential oil constituents, retention index and chemical composition by GC-MS.

\section{REFERENCES}

Аввотт W.S. 1925. A Method of Computing the Effectiveness of an Insecticide. Journal of Economic Entomology, 18 (2): 265-267.

AJAYi O.E., OladipuPo S.O., JEGEDE O.J. 2018. Comparative and synergistic influence of extracts of two tropical plants on the activity of the cowpea weevil, Callosobruchus chinensis. Medicinal Plant Research, 8 (8): 60-73.

BuRKILl H.M. 1985. The useful plants of West Tropical Africa. Edition 2. Vol. 1. Royal Bot. Gard. Kew. The Whitefriars Press Limited, London, England.

Chaubey M.K. 2014. Biological activities of Allium sativum essential oil against pulse beetle, Callosobruchus chinensis (Coleoptera: Bruchidae). Herba Polonica, 60 (2): 41-55.

Chiluwal K., Kim J., Bae S.D., Roh G.H., PARK C.G. 2018. Methyl salicylate and trans-anethole affect the pheromonal activity of homofarnesal, the female sex pheromone of azuki bean beetle. Entomological Research, 48 (5): 345-361.

Chiluwal K., Kim J., Do Bae S., Park C.G. 2017. Essential oils from selected wooden species and their major components as repellents and oviposition deterrents of Callosobruchus chinensis (L.). Journal of Asia-Pacific Entomology, 20 (4): 1447-1453.

CUi S., Wang L., QIU J., LIU Z., GenG X. 2017. Comparative metabolomics analysis of Callosobruchus chinensis larvae under hypoxia, hypoxia/hypercapnia and normoxia. Pest Management Science, 73 (6): 1267-1276.

Curkovic T., Rodríguez D., Huerta A., Bergmann J., Ceballos R. 2018. Behavioral and physiological response of male Callisphyris apicicornis (Coleoptera: Cerambycidae) to virgin con-specific females' extracts. Chilean Journal Agricultural Research, 78 (4): 470-477.

Gbaye O.A., Holloway G.J., Callaghan A. 2012. Variation in the sensitivity of Callosobruchus (Coleoptera: Bruchidae) acetylcholinesterase to the organophosphate insecticide malaoxon: effect of species, geographical strain and food type. Pest Management Science, 68 (9): 1265-1271. 
Gramatica P., Giardina G., Speranza G., Manitto P. 1985. Baker's yeast hydrogenation of carbonyl activated double bonds. Enantioselective synthesis of the (S)-form of the dihydroterpenediol secreted by Danaus chrysippus and of a pheromone of Callosobruchus chinensis L. Chemistry Letters, 14: 1395-1398.

Haddi K., Jumbo L.V., Costa M.S., SAntos M.F., FAROni L.R.A., Serrão J.E., Oliveira E.E. 2018. Changes in the insecticide susceptibility and physiological trade-offs associated with a host change in the bean weevil Acanthoscelides obtectus. Journal of Pest Science, 91 (1): 459-468.

Islam R., Khan R.I., Al-Reza S.M., Jeong Y.T., Song C.H., KhalequZZAman M. 2009. Chemical composition and insecticidal properties of Cinnamomum aromaticum (NEES) essential oil against the stored product beetle Callosobruchus maculatus (F.). Journal of Science and Food Agriculture, 89 (7): 1241-1246.

Koschier E.H., Nielsen M.C., Spangl B., Davidson M.M., Teulon D.A. 2017. The effect of background plant odours on the behavioural responses of Frankliniella occidentalis to attractive or repellent compounds in a Y-tube olfactometer. Entomologia Experimenatalis Applicata, 163 (2): 160-169.

Kumar S., Das G., Shin H.S., Patra J.K. 2017. Dioscorea spp. (A wild edible tuber): A Study on Its Ethnopharmacological Potential and Traditional Use by the Local People of Similipal Biosphere Reserve, India. Frontiers in Pharmacology, 8: 52.

LiNLEY J.R. 1989. Laboratory tests of the effects of $p$-cresol and 4-methyl cyclohexanol on oviposition by three species of Toxorhynchites mosquitoes. Medical and Veterinary Entomology, 3 (4): 347-352.

MarCuS C., LiChtenstein E.P. 1979. Biologically active components of anise: toxicity and interactions with insecticides in insects. Journal of Agricultural and Food Chemistry, 27 (6): $1217-1223$.

Maurin O., Muasya A.M., Catalan P., Shongwe E.Z., Viruel J., Wilkin P., Van Der Bank M. 2016. Diversification into novel habitats in the Africa clade of Dioscorea (Dioscoreaceae): erect habit and elephant's foot tubers. BMC Evolutionary Biology, 16 (1): 238.

Mauti O.G., Peter F.K., JoAn J.E.M., Justus M.O. 2019. Evaluation of the repellent effect of Dioscorea sansibarensis PAX (Dioscoreaceae) leaf essential oil against Bruchus chinensis LiNNAEUS, 1758 (Coleoptera: Bruchidae). Polish Journal of Entomology, 88 (2): 119-128.

NCheKwube E.J., UzoH C.E. 2017. U.S. Patent Application No. 15/119,830.

NTONIFOR N.N., OBEn E.O., KonJe C.B. 2010. Use of selected plant-derived powders and their combinations to protect stored cowpea grains against damage by Callosobruchus maculatus. Journal of Agricultural and Biological Science, 5 (5): 13-21.

Oulebsir-Mohandkaci H., Aissa A.B., Badaoui S., Bouyahiaoui H., Kaki S.A., Mohammedi A. 2018. Comparative study of the toxicity of phenolic compounds of coriander (Coriandrum sativum) and false fennel (Aneth graveolens) on Galleria mellonella (Lepidoptera, Pyralidae). Euro-Mediterranean Journal for Environmental Integration, 3 (1): 30.

Owaga M.L., Hassanali A., Mcdowell P.G. 1988. The role of 4-cresol and 3-n-propyl phenol in the attraction of tsetse flies to buffalo urine. International Journal of Tropical Insect Science, 9 (1): 95-100. 
RANI U., JAMIL K. 1990. Chemosensory responses of cowpea weevil, Callosobruchus chinensis to an aquatic weed, water hyacinth, Eichhornia crassipes (MART) SOLMS. Journal of Chemical Ecology, 16 (4): 1269-1275.

Regnault-Roger C. 1997. The potential of botanical essential oils for insect pest control. Journal of Integrated Pest Management, 2 (1): 25-34.

Salehi T., Karimi J., Hasanshahi G., AskarianZadeh A., Abbasipour H., Garjan A.S. 2014. The effect of essential oils from Laurus nobilis and Myrtus commonis on the adults of Mediterranean flour moth, Ephestia kuehniella ZELLER (Lep.: Pyralidae). Journal of Essential Oil Bearing Plants, 17 (4): 553-561.

Sharma R., Sohal S.K. 2016. Oviposition response of melon fruit fly, Bactrocera cucurbitae (COQUiLLETT) to different phenolic compounds. Journal of Biopesticide, 9 (1): 46-51.

Shibula K., Velavan S. 2015. Determination of phyto-components in methanolic extract of Annona muricata leaf using GC-MS technique. International Journal of Pharmacognosy Phytochemical Research, 7 (6): 1251-1255.

SteVenson P.C., Nicolson S.W., Wright G.A. 2017. Plant secondary metabolites in nectar: impacts on pollinators and ecological functions. Functional Ecology, 31 (1): 65-75.

TALEKAR N.S. 1988. Biology, damage and control of bruchid pests of mung bean. [in:] S. Shanmugasundaram, B.T. MCLEAN (eds.). Mungbean: Proceedings of the second international symposium, Bangkok, Thailand, 16-20 November 1987. AVRDC, Taiwan, 329-342.

Tayade A.B., Dhar P., Kumar J., Sharma M., Chauhan R.S., Chaurasia O.P., Srivastava R.B. 2013. Chemometric profile of root extracts of Rhodiola imbricata EDGEW. with hyphenated gas chromatography-mass spectrometric technique. PLoS One, 8 (1): e52797.

UPADHYAY R.K., AHMAD S. 2011. Management strategies for control of stored grain insect pests in farmer stores and public warehouses. World Journal of Agricultural Science, 7 (5): 527-549.

WaLSh M. 2009. The use of wild and cultivated plants as famine foods on Pemba Island, Zanzibar. Indian Ocean Studies, 42: 217-241.

WINK M. 2018. Plant Secondary Metabolites Modulate Insect Behavior-Steps Toward Addiction. Frontiers in Physiology, 9 (364): 1-9.

Yang S., Mei X.D., Zhang X.F., Li Y.F., She D., Zhang T., Ning J. 2017. Attraction of coffee bean weevil, Araecerus fasciculatus, to volatiles from the industrial yeast Kluyveromyces lactis. Journal of Chemical Ecology, 43 (2): 180-187.

Received: 11 February 2019

Accepted: 24 April 2019 